\title{
Гибридный источник наносекундных импульсов произвольной формы с энергией до 50 мДж
}

\author{
А.И. Трикшев ${ }^{*}$ В.А. Камынин, В.Б. Цветков, \\ В.В. Букин,Т.В. Долматов, Б.Д. Овчаренко \\ Институт общей физики им. А.М. Прохорова РАН \\ ${ }^{*}$ E-mail: trikshevgpi@gmail.com
}

DOI: 10.31868/RFL2020.175-176

Создание мощных лазерных источников наносекундных импульсов является перспективной задачей как в медицине, так и в промышленности [1]. Плавная регулировка формы импульса может позволить более тонко проводить необходимые технологические операции.

Для создания лазерных импульсов заданной формы с энергией в импульсе до 50 мДж использовалась следующая схема (рисунки 1, 2): задающий полупроводниковый лазерный диод с предусилением, связка акустооптического и электрооптического модуляторов, двухпроходный волоконный усилитель и твердотельный оконечный усилитель на Nd:YAG. Развязка каскадов осуществлялась волоконными изоляторами. Для контроля излучения в схему были включены волоконные делители 1/10.

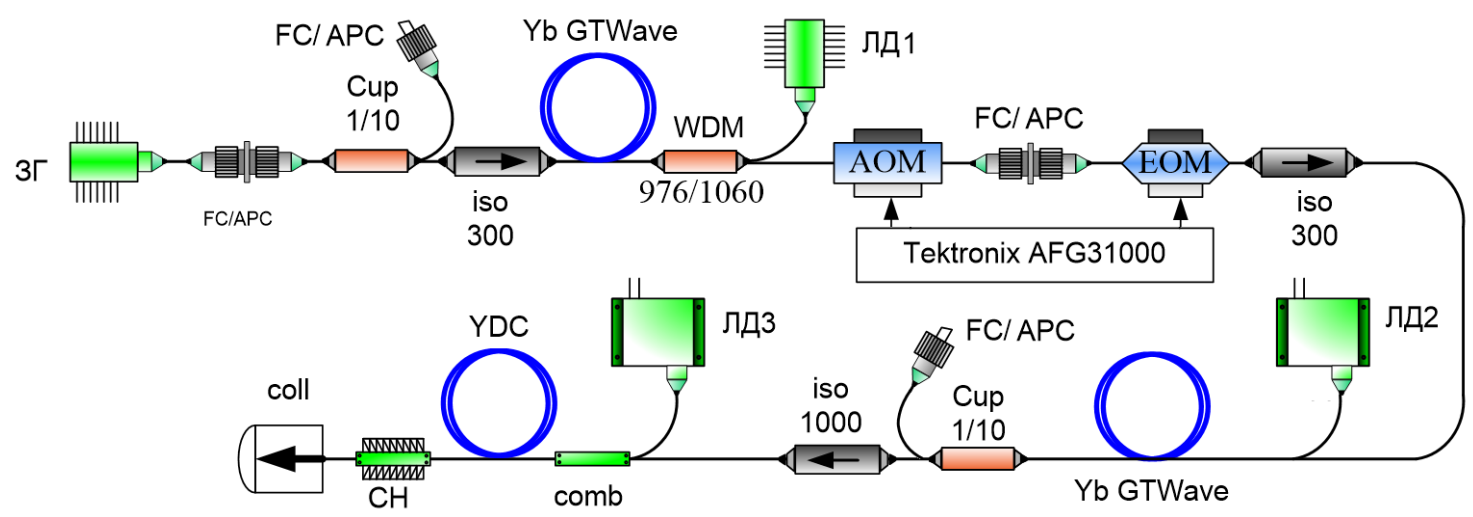

Рис. 1. Схема экспериментальной установки. Волоконная часть.

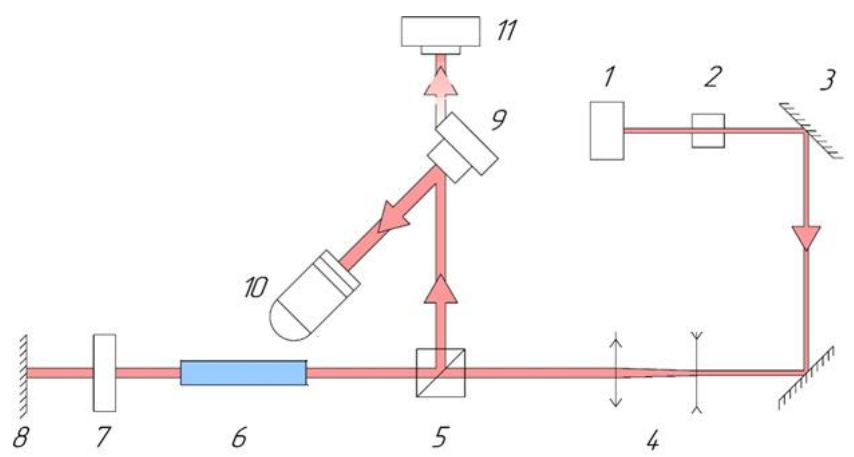

Рис. 2. Схема экспериментальной установки. Твердотельная часть.

1 - волоконный лазер; 2 - призма Глана; 3,8 -зеркало; 4 -2х телескоп; 5 -поляризационный делитель; 6 - усилитель; 7 -пластинка $\lambda / 4$; 9 - датчик пироэлектрический; 10 - фотодиод кремниевый;

$$
11 \text { - КМОП камера }
$$

В качестве задающего генератора (ЗГ) использовался полупроводниковый одночастотный лазерный диод с длиной волны 1064.15 нм и мощностью до 20 мВт с волоконным выходом и ВБР (волоконное брэгговское зеркало). 
В качестве предварительного усилителя использовалось иттербиевое одномодовое волокно длиной 6 м и диаметром сердцевины 6 мкм (NA=0.11). Встречная накачка осуществлялась в сердцевину через волоконный мультиплексор (WDM 980/1064) одномодовым п/п лазерным диодом (ЛД1) с выходной мощностью до 1 Вт на длине волны 976 нм. После усиления было получено излучение мощностью около 400 мВт.

Импульсы заданного профиля формировались связкой акустооптического $(\mathrm{AOM})$ и электрооптического (ЕОМ) модуляторов. На АОМ подавался сигнал прямоугольной формы длительностью около 30 нс. На ЕОМ подавался сигнал требуемого профиля. Такой связкой (АОМ+EOM) суммарно удалось добиться контраста сигнала на уровне лучше 50 дБ. Потери излучения при проходе такой связки составили 5 дБ. В качестве генератора сигналов использовался Tektronix AFG 31000 с частотой дискретизации $2 \mathrm{Gs} / \mathrm{s}$ и полосой 250 МГц, что позволило формировать импульсы с разрешением в 4 нс.

Импульсы усиливались в иттербиевом GTWave волокне [2] длиной 9 м и диаметром сердцевины 6 мкм (NA=0.11). Накачка осуществлялась многомодовым полупроводниковым лазерным диодом (ЛД2) на длине волны 976 нм. При этом энергия импульсов на выходе составила около 0.5 мкДж.

В качестве оконечного усилителя применялось иттербиевое волокно с двойной оболочкой с диаметром сердцевины 6 мкм $(\mathrm{NA}=0.11)$. Попутная накачка осуществлялась с помощью волоконного комбайнера (comb) многомодовым п/п лазерным диодом на длине волны 976 нм (ЛД3). Непоглощенная накачка выводилась с помощью съемника непоглощенной накачки $(\mathrm{CH})$. Основное излучение выводилось через сколотый под прямым углом торец и фокусировалось коллиматором (coll). После усиления была получена энергия импульсов до 3 мкДж. Осциллограмма профилированного импульса представлена на рис. 3.a.

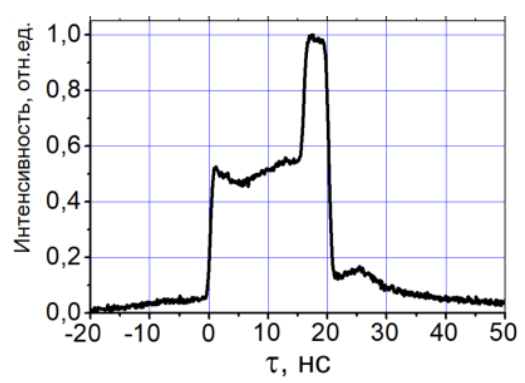

a)

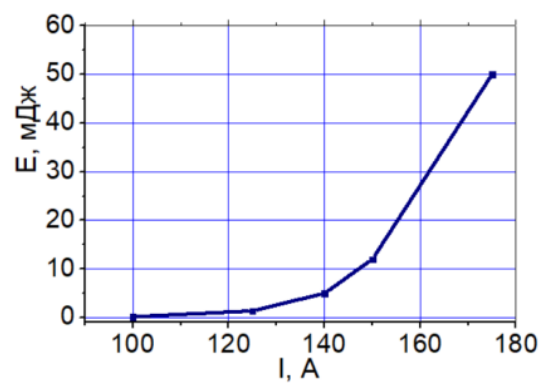

б)

Рис. 3. а) Осциллограмма профилированного импульса,

б) зависимость энергии прямоугольных импульсов от тока накачки квантрона.

В качестве оконечного усилителя применялся твердотельный усилитель на $\mathrm{Nd}$ :YAG (стержень диаметром 5 мм и длиной 10 см). Импульсная накачка осуществлялась п/п модулями накачки с максимальной мощностью 20 кВт (при токе накачки в 225 А). Длительность импульса накачки составляла 250 мкс. Усиление отрабатывалось на прямоугольных импульсах длительностью 20 нс. Максимальная энергия в импульсе после двух проходов усиления составила около 50 мДж (рис.3.б) при токе накачки в 175 А. При дальнейшем увеличении тока накачки усилитель переходил в режим генерации.

\section{Литература}

[1] Meijer R. A., Stodolna A. S., et al, Optics Letters, 42(14), 2758-2761

[2] Bufetov I.A., Bubnov M.M., et.al., Quantum Electronics, 35, 328 (2005). 